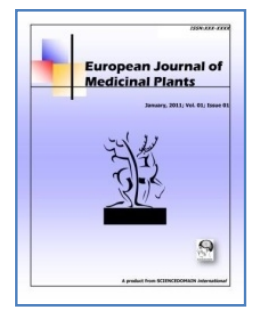

\title{
In vivo Antimalarial Activity of Stem Bark of Dry Zone Cedar Pseudocedrela kotschyi (Meliaceae) in Mice
}

\author{
A. Dawet ${ }^{1^{*}}$, D. P. Yakubu ${ }^{1}$, N. N. Wannang ${ }^{2}$ and G. S. Mwansat ${ }^{1}$ \\ ${ }^{1}$ Department of Zoology, Faculty of Natural Sciences, University of Jos, P.M.B. 2084, Jos, \\ Nigeria. \\ ${ }^{2}$ Department of Pharmacology, Faculty of Pharmaceutical Sciences, University of Jos, \\ P.M.B. 2084, Jos, Nigeria.
}

\section{Authors' contributions}

This work was carried out in collaboration between all authors. Authors AD and DPY designed and carried out the study, performed the statistical analysis, and wrote the

first draft of the manuscript. Author NNW wrote the protocol and proof red the manuscript. Author GSM managed the literature searches. All authors read and approved the final manuscript.

Original Research Article

Received $18^{\text {th }}$ December 2012

Accepted $14^{\text {th }}$ February 2013

Published $12^{\text {th }}$ January 2014

\section{ABSTRACT}

Background: Malaria infection remains the most devastating infectious parasitic disease responsible for the death and economic losses among half the world's population. The development of resistance to the present antimalarial drugs by Plasmodium species has necessitated the search for effective antimalarial drugs. The stem bark of dry zone cedar (Pseudocedrela kotschyi) Meliaceae is used locally for the treatment of fever, hence the choice of the plant to prove scientifically the traditional claim.

Aim: The aim of the study was to evaluate the antimalarial activity of the stem bark extracts of $P$. kotschyi in mice.

Methodology: One hundred and twenty grammes of the plant powder were successively extracted. A total of three hundred and sixty mice were used for the study, one hundred and twenty for each extract (ethanol, ethyl acetate and aqueous) and forty per each test (suppressive, curative and prophylactic). Male and female, albino mice were inoculated with drug sensitive NK 65 Plasmodium berghei berghei. In each test animals were divided into five groups, each consisted of eight animals and treated separately with one of the 
following: 50, 100 and $200 \mathrm{mg} / \mathrm{kg}$ extracts, chloroquine / pyrimethamine and normal saline. Blood films were prepared and examined.

Results: The ethanol, ethyl acetate and aqueous crude extracts of $P$. kotschyi at 200 $\mathrm{mg} / \mathrm{kg}$ significantly $(\mathrm{P}<0.05)$ inhibited the parasitaemia by $39.43 \%, 26.99 \%$ and $28.36 \%$ respectively in the suppressive test. Ethanol and ethyl acetate crude extracts also showed significant $(p<0.05)$ cure rate of $29.17 \%$ and $20.28 \%$ respectively. However there was no significant $(p>0.05)$ reduction in parasitaemia load in the prophylactic tests, indicating that the plant is probably not a potential prophylactic subject.

Conclusion: The results of the study showed that $P$. kotschyi indeed has antiplasmodial property, which could be exploited in the search for malaria drugs in the present day scenerio.

Keywords: Antimalarial; screening; Pseudocedrela kotschyi; mice.

\section{INTRODUCTION}

Malaria is entirely preventable and treatable vector-borne disease which account for an estimated 219 million cases globally, killing about 660,000 people, mostly children under five years of age. The burden is concentrated in 14 endemic countries, which account for an estimated $80 \%$ of malaria deaths [1]. Over $90 \%$ of the deaths attributable to the disease occur in African region and $86 \%$ of these deaths are among children [2].

Malaria is caused by a eukaryotic protist of the genus Plasmodium. There are four distinct species that infect humans: P. falciparum, P. vivax, P.malariae and P.ovale. A fifth species, $P$. knowlesi, is a zoonotic that causes malaria in macaques but can also infect humen [3].The parasites are naturally transmitted by the female Anopheles mosquito from the blood of an infected host to the blood of an uninfected.

The clinical features of malaria vary. The most characteristic symptom is the occurrence of paroxysm which include fever with temperatures of up to $40-41^{\circ} \mathrm{C}$ at regular intervals every 48 or 72 hours (tertian or quartan), alternating with good periods of no fever. This is preceded by headache, lassitude, loss of appetite, muscle pain and chills, resulting in uncontrollable shivering with teeth chattering. This is accompanied by thirst, nausea, vomiting [4]. Severe and complicated malaria causing renal failure, hypoglycemia, anemia, pulmonary oedema, shock and coma can have fatal consequences, leading to death. According to [5], malaria usually results in increased maternal mortality and morbidity and the delivery of premature infants or infants who have low weights for their gestational ages.

Malaria transmission can be reduced by preventing mosquito bites by distribution of inexpensive mosquito nets and insect repellants, or by mosquito control measures such as spraying insecticides inside houses and drainage of stagnant water where mosquitoes lay their eggs. A wide variety of antimalarial drugs are available to treat malaria. In the last few years, treatment of $P$. falciparum infections in endemic countries has been transformed by the use of combinations of drugs containing an artemisinin derivative. Severe malaria is treated with intravenous and intramuscular quinine or increasing, the artemisinin derivative artesunate [6]. Efforts to reduce the high malaria morbidity and mortality rates have been hampered by the development of resistance, particularly by $P$. falciparum to long-standing inexpensive conventional drugs such as chloroquine $[7,8,9,10]$. This set back in the drug control and eradication of malaria has necessitated the identification of new effective alternative drugs. Although many are under development, the challenge of producing a 
widely available vaccine that provides a high level of protection for a sustained period is still to be met [11].

Since malaria continues to exist with its great immeasurable devastating effects on human and animals and parasites showing resistance to the existing antimalarial drugs, there is a need to explore our abundant plant resources for the development of new drugs or vaccines for the treatment, prevention and management of the disease. The stem bark of $P$. kotschyi (Dry zone cedar) is used locally for the treatment of fever in Plateau State; hence the choice of the plant to prove scientifically the traditional claim. It is on this basis that the present study is carried out to determine the in-vivo antiplasmodial property of $P$. kotschyi. on $P$. berghei berghei in mice.

Plants continue to play a key role in health care systems, indeed it is estimated that up to $80 \%$ of the world populations utilize traditional medicines for the treatment of diseases. The majority of African populations use traditional medicine for their health care needs. The medicaments are often bought in places such as open markets and local stores [12,13,14]. $P$. kotschyi Harm (Meliaceae) is used for various purposes. [15] reported the inhibition of $P$. falciparum trophozoites transformation into schizonts by $P$. kotschyi root extract. [16] reported that the ethanolic stem bark extract of $P$. kotschyi reduced the trypanosomal load; prolonging the survival of Trypanosoma brucei brucei infected rats. The dichloromethane extract of $P$. kotschyi root demonstrated marked antiprotozoal activity against Leishmania, Trypanosoma and Plasmodium [17]. The ethanolic extract of the plant was reported active against Haemonchus contortus [18]. [19] in their in vitro evaluation of some plants used by the Karimojong (Uganda) pastoralists for ascaricidal activity reported that $P$. kotschyi had significant activity against Ascaris suum.

\section{MATERIALS AND METHODS}

\subsection{Experimental Animals}

Ethical approval was obtained from the ethical committee of the Animal House, University of Jos, Jos, Nigeria. Animals were treated as approved by international standard for the treatment of experimental animals. Four weeks old Male and female albino mice, free from Plasmodium parasites, weighing $18-23 \mathrm{~g}$ used in the study, were obtained from the animal house, University of Jos. They were fed on a standard rodent's diet consisting of crude protein, fat, calcium, available phosphate, vitamins, crude fibre and constant supply of water, in plastic cages measuring $25 \mathrm{~cm} \times 20 \mathrm{~cm} \times 10 \mathrm{~cm}$ with a metal cover for free passage of air, at room temperature of about $27^{\circ} \mathrm{C}$.

\subsection{Parasite Species}

Chloroquine sensitive $P$. berghei berghei NK 65 was used to test the plant extracts. The parasites were obtained from the National Institute for Pharmaceutical Research and Development (NIPRD) Idu-Abuja and the Department of Biochemistry, Ahmadu Bello University Zaria, Nigeria by inoculation of uninfected mice with blood from $P$. berghei infected mice. The parasites were maintained by successive inoculations of parasite free mice every four or five days with $0.2 \mathrm{ml}$ of the diluted blood from the infected mice using one (1) $\mathrm{ml}$ Syringe and needle. 


\subsection{Preparation of Plant Materials}

The plant used for the study was $P$. kotschyi (Meliaceae). It was obtained from Tim along Mangu - Bwai road in Mangu Local Government Area, Plateau State, Nigeria and identified by taxonomists from the Federal College of Forestry Jos and Department of Plant Science and Technology, University of Jos, Jos. A voucher specimen was deposited at the the Federal College of Forestry, Jos and in the Department of Pharmacognosy, University of Jos, Jos with specimen numbers SF00108J and UJ/PGNS/HSP/0901 respectively. The stem parts of the plants above the soil were removed using a knife or axe. The stem were peeled and dried under shade as described by [20]. The dried materials were ground to powder using mortar and pestle.

\subsection{Extraction of Plant Materials}

This stem powder was successively (serially) extracted in a similar method described by [21, 22] starting with ethyl acetate, followed by ethanol and then water. 120 grammes of the powdered stem bark was measured and transferred into a flask and 2.5 liters of each solvent was added and caped with the cover in each step to macerate for 24 hours with intermittent agitations. The marc was always removed and dried to evaporate the solvents before reintroducing into the container for each subsequent extraction. The extracts were collected in a flask and concentrated to dryness using a rotary evaporator and water bath at $40-60^{\circ} \mathrm{C}$. The percentage yield for each sample was determined and crude extracts were stored in a refrigerator at $4^{\circ} \mathrm{C}$ for further use.

\subsection{Experimental Design}

A total of three hundred and sixty mice were used for the study, one hundred and twenty for each extract (ethanol, ethyl acetate and aqueous) and forty per each test (suppressive, curative and prophylactic). In each test, forty mice were randomly inoculated with $0.2 \mathrm{ml}$ diluted blood containing $1.2 \times 10^{7}$ parasitized red blood cells to study the effect of stem bark extract. The animals were divided into five groups, each consisting of eight animals. Three of the five groups were each administered one of the following: $50 \mathrm{mg} / \mathrm{kg}, 100 \mathrm{mg} / \mathrm{kg}$ or 200 $\mathrm{mg} / \mathrm{kg}$ of the extract, one of the two remaining groups (control 1) received $0.2 \mathrm{ml}$ of the vehicle (normal saline) while the other group (control 2) received $5 \mathrm{mg} / \mathrm{kg}$ of chloroquine phosphate or pyrimethamine. Every mouse was treated once daily with the dosage for four (in suppressive and prophylactic tests) or five (in curative test) consecutive days and the level of parasitaemia were examined.

\subsection{Antimalarial Activity}

\subsubsection{4-Day suppressive test}

The suppressive test was conducted in a similar method used by $[23,24]$. 40 Mice were divided into 5 groups of 8 animals each. Three of the 5 groups were each administered one of the following: $50 \mathrm{mg} / \mathrm{kg}, 100 \mathrm{mg} / \mathrm{kg}$ or $200 \mathrm{mg} / \mathrm{kg}$ of the extract. One of the remaining groups was administered $0.2 \mathrm{ml}$ normal saline (control 1) while the other group received chloroquine phosphate $(5 \mathrm{mg} / \mathrm{kg}$ ) (control 2). Each mouse was inoculated on the first day (Do), intraperitoneally, with infected blood containing $P$. berghei berghei parasitized red blood cells. The mice were treated daily from day 0 (immediately after infection) to day 3 . Thin smears fixed in methanol stained with Giemsa stain were prepared from the tail blood 
of each mouse daily from day 4 to day 7 , examined microscopically under oil immersion and the percentage parasitaemia was determined by counting the parasitized erythrocytes in at least ten random fields. The mean parasite count for each group was determined and the average percentage chemosuppression for each dose was calculated as $[(A-B) / A]$, where $A$ is the average percentage of parasitaemia in the normal saline group (control 1 ) and $B$ is the average percentage of parasitaemia in the test groups.

\subsubsection{Rane (Curative) test}

This was conducted in a similar method adopted by [20,24]. Another set of 40 albino mice were infected with parasitized erythrocytes. Seventy-two hours after infection, the mice were divided into 5 groups of 8 animals each. Three of the 5 groups were each administered one of the following: $50 \mathrm{mg} / \mathrm{kg}, 100 \mathrm{mg} / \mathrm{kg}$ or $200 \mathrm{mg} / \mathrm{kg}$ of the extract. The fourth group (control 1) was given $0.2 \mathrm{ml}$ normal saline while the last group (control 2) received $5 \mathrm{mg} / \mathrm{kg}$ of chloroquine phosphate. Each mouse was treated orally once daily with the dose for 5 consecutive days (D4 - D8) post inoculation during which the parasitaemia level was monitored daily.

\subsubsection{Repository (Prophylactic) test}

This was carried out according to the method of [25]. The mice were divided into 5 groups of 8 animals each. Three of the 5 groups were each administered one of the following: 50 $\mathrm{mg} / \mathrm{kg}, 100 \mathrm{mg} / \mathrm{kg}$ or $200 \mathrm{mg} / \mathrm{kg}$ of the extract. The fourth group (control 1) was given $0.2 \mathrm{ml}$ normal saline while the last group (control 2) received $1.2 \mathrm{mg} / \mathrm{kg}$ of pyrimethamine for four consecutive days. On day four the mice were inoculated with $P$. berghei berghei. Seventy two hours later (D3), smears were made from the mice (D3-D7) and the parasitaemia levels assessed.

\subsection{Inoculation of Animals}

Inoculation of mice was done as carried out by $[26,27]$. The animal was held at the back and neck and the tail between fingers. The peritoneal region was cleaned with cotton wool moistened with alcohol and allowed to dry.

Each mouse received intraperitoneally a standard inoculum of about $1.2 \times 10^{7} P$. berghei infected erythrocytes on day zero $\left(D_{0}\right)$. The injected site was cleaned with cotton wool moistened with alcohol after inoculation.

\subsection{Administration of Extracts and Drugs}

The extract and drugs employed in this study were administered orally with the aid of a cannula connected to one (1) $\mathrm{ml}$ syringe. The required dose was given according to the weight of the animal four hours after inoculation of parasites on $D_{0}$, then once daily for three more days $\left(D_{1}-D_{3}\right)$

\subsection{Evaluation of Parasitaemia}

Thin blood films of infected and treated mice were prepared and examined for parasitaemia level under the microscope from day four through day seven $\left(D_{4}-D_{7}\right)$. The stained slides were mounted in oil immersion. Red cells were counted in 10 fields and the parasitized ones 
were marked down on a paper, then the percentage parasitaemia in a group was calculated as:

Percentage parasitaemia $=$

Number of parasitised cells x 100

The average percentage suppression for each dose of each extract was calculated in comparison to controls according to $[20,26]$ as:

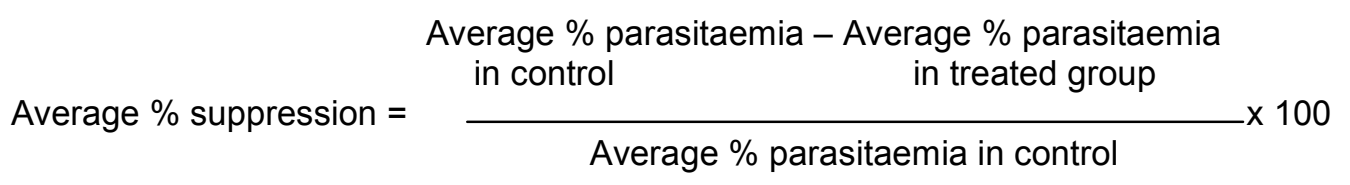

\subsection{Statistical Analysis}

Data were analysed using one way analysis of variance (ANOVA) and students t-test coupled Least Significant Difference (LSD) to compare the parasitaemia of mice between doses and among treatment and control (normal saline) group.

\section{RESULTS}

The percentage yields of crude extracts of $P$. kotschyi stem bark after evaporation were 20.4 $\mathrm{g}(17 \%), 10.2 \mathrm{~g}(8.5 \%)$, and $1.92 \mathrm{~g}(1.6 \%)$ in ethanol, aqueous and ethyl acetate respectively. The in-vivo antimalarial activity of the ethanol extract of the suppressive test showed significant difference $(P<0.05$ and 0.01$)$ between the extract treated and the normal saline control 1 (Table 1). The administration of $200 \mathrm{mg} / \mathrm{kg}$ in the curative test produced a significant difference $(P<0.05)$ compared with the untreated group, while there was no statistical significant difference $(P>0.05)$ between the treated and the untreated control 1 group in the prophylactic test. The ethanol extract produced the highest inhibition in the suppressive test, followed by curative and prophylactic with $39.04 \%, 29.17 \%$ and 6.53 $\%$ respectively in groups given $200 \mathrm{mg} / \mathrm{kg}$. The standard drugs produced a significant difference $(P<0.05)$ in all the tests compared with the normal saline group with percentage inhibition of $95.04 \%, 93.54 \%$ and $92.05 \%$ in the suppressive, curative and prophylactic test respectively.

A significant difference $(P<0.05)$ between the extract treated and the untreated groups was observed only in the group given $200 \mathrm{mg} / \mathrm{kg}$ in the suppressive test (Table 2). The average percentage inhibition of parasitaemia of the extract treated groups were generally low with $28.36 \%, 17.15 \%$ and $21.97 \%$ at $200 \mathrm{mg} / \mathrm{kg}$ in the suppressive, curative and prophylactic tests respectively, while the standard drugs had a higher inhibition of more than $90 \%$.

The ethyl acetate administration activity showed a significant difference $(P<0.05)$ between the groups treated at $200 \mathrm{mg} / \mathrm{kg}$ in the suppressive and curative tests (Table 3 ). The percentage inhibition at $200 \mathrm{mg} / \mathrm{kg}$ were $26.99,20.28$ and 14.40 in the suppressive, curative and prophylactic test respectively, while significant $(P<0.05)$ inhibition in groups given the standard drugs were greater than ninety percent. 
Table 1. Antimalarial activity of $P$. kotschyi ethanol stem bark extract in $P$. berghei berghei infected mice

\begin{tabular}{llll}
\hline Test & Dose $(\mathbf{m g} / \mathbf{k g})$ & $\begin{array}{l}\text { Parasitaemia (\%) } \\
\text { mean } \pm \text { S.E }\end{array}$ & \% Inhibition \\
\hline Suppressive & NS $0.2 \mathrm{ml}$ & $20.77 \pm 2.11$ & - \\
& Ext. 50 & $15.08 \pm 1.5^{*}$ & 27.40 \\
& Ext. 100 & $13.70 \pm 1.44^{*}$ & 34.04 \\
& Ext. 200 & $12.58 \pm 1.3^{*}$ & 39.43 \\
Curative & CQ 5 & $1.03 \pm 0.17^{*}$ & 95.04 \\
& NS 0.2 ml & $24 \pm 2.5$ & - \\
& Ext. 50 & $22.5 \pm 2.4$ & 6.25 \\
& Ext. 100 & $20.13 \pm 2.12$ & 16.13 \\
& Ext. 200 & $17 \pm 1.62^{*}$ & 29.17 \\
Prophylactic & CQ 5 & $1.55 \pm 1.03^{*}$ & 93.54 \\
& NS 0.2 ml & $21.13 \pm 2.14$ & - \\
& Ext. 50 & $20.68 \pm 2.01$ & 2.13 \\
& Ext. 100 & $20.73 \pm 2.08$ & 1.89 \\
& Ext. 200 & $19.75 \pm 1.76$ & 6.53 \\
& PM 1.2 & $1.68 \pm 0.23^{*}$ & 92.05 \\
\hline
\end{tabular}

NS- Normal saline, Ext- Extract, CQ- Chloroquine, PM- Pyrimethamine.

SE- Standard error for 8 mice in each dose

* $P<0.05$ compared to control group (student's $t$ - test).

Table 2. Antimalarial activity of $P$. kotschyi aqueous stem bark extract in $P$. berghei berghei infected mice.

\begin{tabular}{llll}
\hline Test & Dose $(\mathbf{m g} / \mathbf{k g})$ & $\begin{array}{c}\text { Parasitaemia (\%) } \\
\text { mean } \pm \text { S.E }\end{array}$ & \% Inhibition \\
\hline Suppressive & NS 0.2 ml & $20.7 \pm 2.06$ & - \\
& Ext. 50 & $18.68 \pm 2.01$ & 9.76 \\
& Ext. 100 & $17.28 \pm 1.89$ & 16.52 \\
& Ext. 200 & $14.83 \pm 1.52\left(^{*}\right)$ & 28.36 \\
& CQ 5 & $2.05 \pm 0.26\left(^{*}\right)$ & 90.10 \\
Curative & NS 0.2 ml & $23.03 \pm 2.49$ & - \\
& Ext. 50 & $21.75 \pm 2.42$ & 5.56 \\
& Ext. 100 & $20.88 \pm 2.34$ & 9.34 \\
& Ext. 200 & $19.08 \pm 1.94$ & 17.15 \\
Prophylactic & CQ 5 & $2.25 \pm 0.13\left(^{*}\right)$ & 90.23 \\
& NS 0.2 ml & $22.3 \pm 2.36$ & - \\
& Ext. 50 & $19.5 \pm 2.22$ & 12.56 \\
& Ext. 100 & $17.93 \pm 2.07$ & 19.60 \\
& Ext. 200 & $17.4 \pm 1.96$ & 21.97 \\
& PM 1.2 & $1.65 \pm 0.15\left({ }^{*}\right)$ & 92.60 \\
\hline
\end{tabular}

NS- Normal saline, Ext- Extract, CQ- Chloroquine, PM- Pyrimethamine.

SE- Standard error for 8 mice in each dose.

${ }^{*} P<0.05$ compared to control group (student's $t$ - test) 
Table 3. Antimalarial activity of $P$. kotschyi ethyl acetate stem bark extract in $P$. berghei berghei infected mice

\begin{tabular}{llll}
\hline Test & Dose $(\mathbf{~ m g} / \mathbf{k g})$ & $\begin{array}{c}\text { Parasitaemia (\%) } \\
\text { mean } \pm \text { SE }\end{array}$ & \% Inhibition \\
\hline Suppressive & NS 0.2 ml & $25.88 \pm 2.41$ & - \\
& Ext. 50 & $24.28 \pm 2.28$ & 6.18 \\
& Ext. 100 & $22.3 \pm 1.80$ & 13.83 \\
& Ext. 200 & $20.38 \pm 1.51\left(^{*}\right)$ & 26.99 \\
Curative & CQ 5 & $2.1 \pm 0.27\left(^{*}\right)$ & 91.89 \\
& NS 0.2 ml & $24.9 \pm 2.43$ & - \\
& Ext. 50 & $25.15 \pm 2.40$ & 1.00 \\
& Ext. 100 & $24.38 \pm 2.23$ & 2.09 \\
& Ext. 200 & $19.85 \pm 1.68\left(^{*}\right)$ & 20.28 \\
Prophylactic & CQ 5 & $2.45 \pm 0.37\left(^{*}\right)$ & 90.16 \\
& NS 0.2 ml & $24.45 \pm 2.33$ & - \\
& Ext. 50 & $24.13 \pm 2.41$ & 1.31 \\
& Ext. 100 & $23.40 \pm 2.27$ & 4.29 \\
& Ext. 200 & $20.93 \pm 1.95$ & 14.40 \\
& PM 1.2 & $2.03 \pm 0.28\left(^{*}\right)$ & 91.70 \\
\hline & NS- Normal saline, Ext- Extract, CQ- Chloroquine, PM- Pyrimethamine. \\
& SE- Standard error for 8 mice in each dose & \\
& ${ }^{*} P<0.05$ compared to control group (student's t- test).
\end{tabular}

\section{DISCUSSION}

The study revealed that the ethanolic extract of the plant reduced parasitaemia by $39.43 \%$ when tested at an oral dose of $200 \mathrm{mg} / \mathrm{kg}$, indicating that the effective dose of each extract was greater than $200 \mathrm{mg} / \mathrm{kg}$. Reduction in parasitaemia was more evident in the groups administered with ethanol extract than in those tested with the aqueous and ethyl acetate extracts. The highest antimalarial activity produced by ethanol than water extract is consistent with [28] who reported highest in vitro antiplasmodial activity in organic solvents of Cassia arereh. However, water is the extraction solvent mostly use in traditional medicine in endemic areas. The extract produced dose -dependent relationship, with the higher doses resulting in greater reduction in the parasite density/ load than the lower doses. The highest antimalarial suppression of $39.43 \%$ observed in this study is low compared with $69.46 \%$ reported by [29], 81.36\% [30], 66.67\% [31] and 79.5\% [32]. The low parasitaemia recorded in this study may be due to low dose which could be increased to give higher inhibition rate and at the same time considering the toxicity of the extract. However, [33] demonstrated that the antimalarial activity of a compound and its toxicity are not directly related. The low dose effect is confirmed by the report of [20] that inhibition of $P$. berghei by the extracts of $M$. morindoides, $P$. niruri and C. occidentalis at $200 \mathrm{mg} / \mathrm{kg}$ was less than at $800 \mathrm{mg} / \mathrm{kg}$. However it is in line with the finding of [34] that lethality of Ae aegypti and C. quinquefaciatus larvae were more pronounced with increasing concentration of Lantana camara.

The standard drug 5 and $1.2 \mathrm{mg} / \mathrm{kg}$ (Chloroquine phosphate and pyrimethamine respectively) on the other hand significantly $(P .<0.05)$ inhibited parasitaemia level by more than $90 \%$. The low parasitaemia in these groups was due to the inhibition of the enzyme, dihydrofolate reductase involved in biosynthesis of folic acid an essential precursor in the formation of nucleic acids and also due to the action of the drug (Chloroquine phosphate/pyrimethamine) on the parasite lysosomal membrane. 
[24] reported that Vernonia amygdalina, aqueous leaf extract at dose of $125 \mathrm{mg} / \mathrm{kg}$ had the inherent ability to work in favour of the restoration of chloroquine efficacy as a prophylactic and chemotherapeutic agent against chloroquine sensitive and resistant Plasmodium berghei infection in mice.

\section{CONCLUSION}

The result of this study showed that the stem bark extract of $P$. kotschyi is not a prophylactic remedy against Plasmodium parasites since various solvent extracts had no significant $(\mathrm{P}>$ 0.05 ) prophylactic effect. However, it could probably be a potential chemotherapeutic agent which is evidenced in the suppressive and curative tests. The result of this study indicates that $P$. kotschyi stem bark extracts have antimalarial potentials, therefore the plant should be extensively investigated to isolate and identify their antimalarial active constituents. The present study has shown scientifically for the first time that $P$.kotschyi stem bark indeed has antimalarial property, so these findings support the traditional uses of the plant and this can be explored in the field of drug production for malaria.

\section{CONSENT}

Not applicable.

\section{ETHICAL APPROVAL}

All authors hereby declare that "Principles of laboratory animal care" (NIH publication No. $85-23$, revised 1985) were followed, as well as specific national laws where applicable. All experiments have been examined and approved by the appropriate ethics committee.

\section{COMPETING INTERESTS}

Authors have declared that no competing interests exist.

\section{REFERENCES}

1. World Health Organization. New report signals slowdown in the fight against malaria. Available:http://www.who.int/mediacentre/news/releases/2012/malaria 2012117/en/in dex.html.

2. World Health Organization World Malaria Day. Available:htt://www.afro.who.int/en/clusters-a-programmes/dpc/malaria/features/3603world malaria-day-2012.html.

3. Singh B, Sung LK, Matusop A, Radhakrishnan A, Shamsul SSG, Cox-Singh J, Thomas A, Conway DJ. A large focus of naturally acquired Plasmodium knowlesi infections in human beings. The Lancet. 2004;363(9414):1017-1024.

4. Ukoli FMA. The biology and natural history of malaria. An Int. J. Med. Sc. 2000;1(2): 35-36.

5. McGregor IA. Epidemiology, malaria and pregnancy. J. Trop. Med. Hygiene. 1984;33(4):517-525.

6. Dondorp AM, Day NPJ. The treatment of severe malaria. Ann. Trop. Med. Hygiene. 2007;101(7):633-634. 
7. Okoyeh JN, Lege-Oguntoye L, Emembolu JO, Sarki U, Slotboom AB. Sensitivity of $P$. falciparum to chloroquine in pregnant women in Zaria, Northern Nigeria. Trop. Geograph. Med. 1993;45(2):56-58.

8. Ejov MN, Tun T, Aung S, Sein K. Response of falciparum malaria to different antimalarials in Myanmar. World Health Organization. 1999;77(3):244-249.

9. Wellems TE. Plasmodium chloroquine resistance and the search for a replacement antimalaria drug. Science. 2002;298(5591):124-126.

10. Wongsrichanalai C, Pickard AL, Wernsdorfer WH, Meshnick SR. Epidemiology of drug-resistant malaria. Lancet Infect. Dis. 2002;2(4):209-218.

11. Kilama W, Ntoumi F. Malaria: a research agenda for the eradication era. The Lancets. 2009;374(9700):1480-1482.

12. Hostettmann $\mathrm{K}$, Marston A.Twenty years of research into medicinal plants: results and perspectives. Phytochem. Review. 2002;1(3):275-285.

13. World Health Organization Herbal Medicines. W.H.O. Drug Information. 2004;18(1):27-29.

14. World Health Organisation. Traditional medicine; 2009.

Available: http://www.who.int/topics/traditional medicine/en/.

15. Kassim OO, Loyevsky M, Amonoo H, Lashley L, Ako-Nai KA, Gordeuk VR. Inhibition of in-vitro growth of Plasmodium falciparum by Pseudocedrela kotschyi extract alone and in combination with Fagara zanthoxyloides extract. Ann. Trop. Med. Hygiene. 2009;103(7):698-702.

16. Dawet A, Yakubu DP, Igwebike EA. Trypanocidal activity and haematoxicity of Pseudocedrela kotschyi harms (Meliaceae) ethanolic stem bark extract in Trypanosoma brucei brucei infected rats. Biol. Environ. Scs. J. Trop. 2011;8(1):137142.

17. Hay AE, loset JR, Ahua KM, Diallo D, Brun R, Hostettmann K. Limonoid orthoacetates and antiprotozoal compounds from the roots of Pseudocedrela kotschyi. J. Nat. Products. 2007;70(1):9-13.

18. Koné WM, Atindehou KK, Dossahoua T, Betschart B. Anthelmintic activity of medicinal plants used in northern Côte d'Ivoire against intestinal helminthiasis. Pharm. Biol. 2005;43(1):72-78.

19. Emaruk E, Deogracious O. Ascaricidal activity of some medicinal plants used by the Karimojong: A nomadic pastoralist community in Uganda. J. Anim. Vet. Advances. 2006;5(9):724-728.

20. Tona L, Mesia K, Ngimbi NP, Chrimwami B, Okond' Ahoka, Cimanga K, Debroyne T, Apers S, Hermans N, Totte J, Pieters L, Vlietinck AJ. In -vivo antimalarial activity of Cassia occidentalis, Morinda morindoides and Phyllanthus niruri. Ann. Trop. Med. Parasitol. 2001;95(1):47-57.

21. Akah PA, Onyirioha CA, Nworu CS, Ndu OO. Gastro-protective effects of the leaf extract and fractions of Fleurya aestuans L. (Urticaceae). Inter. J. Health Res. 2009;2 (1):65-73.

22. Mohammed EAH, Mohammed AJ, Asmawi MZ, Sadikun A, Ebrika OS, Yam MF. Antihyperglycemic effect of Orthosiphon stamineus Benth leaves extract and its bioassay-guided fractions. Molecules. 2011;16(5):3787-3801.

23. Mesia GK, Tona GL, Penge O, Lusakibanza M, Nanga TM, Cimanga RK, Apers S, Van Miert S, Totte J, Pieters L, Vlietinck AJ. Antimalarial activities and toxicities of three plants used as traditional remedies for malaria in the Democratic Republic of Congo: Croton mubango, Nauclea pobeguinii and Pyrenacantha staudtii. Ann. Trop. Med. Parasitol. 2005;99(4):345-357. 
24. Iwalokun BA. Enhanced antimalarial effects of chloroquine by aqueous Vernonia amygdalina leaf extract in mice infected with chloroquine resistant and sensitive Plasmodium berghei strains. Afric. Health Scs. 2008;8(1):25-35.

25. Peters W. Drug resistance in Plasmodium berghei I. Chloroquine resistance. Experiment. Parasitol. 1965;17(1):80-89.

26. Awe SO, Makinde JM. Antiplasmodial activity of Carica papaya against Plasmodium yoelli nigeriensis in mice. West Afric. J. Pharm. Drug Res. 1997a;13:1-7.

27. Awe SO, Makinde JM. Evaluation of the anti - malarial activity of Morinda lucida using both in vivo and in vitro techniques. West Afric. J. Pharm. Drug Res. 1997b;13:325331.

28. Imam H, Abd Alla AEWH, Yagi SM. Evaluation of the larvicidal, antiplasmodial and cytotoxicity properties of Cassia arereh Del. stem bark. Europ. J. Med. Plants. 2013;3 (1):78-87.

29. Pinmai K, Hiriote W, Soonthornchareonnon N, Jongsakul K, Sireeratawong S, TorUdom S. In vitro and In vivo anti-plasmodial activity and cytotoxicity of water extracts of Phyllanthus emblica, Terminalia chebula and Terminalia bellerica. J. Med. Assoc. Thail. 2010;93(Suppl.7):S120-S126.

30. Madara AA, Ajayi JA, Salawu OA, Tijani AY, Iserhien NI. Anti- plasmodial activity of ethanolic stem bark extract of Piliostigma thonningii Schum (Caesalpiniaceae) in mice infected with Plasmodium berghei berghei. Nig. J. Parasitol. 2010;31(2):102-107.

31. Unekwuojo EG, James O, Olubunmi AR. Suppressive, curative and prophylactic potentials of Morinda lucida (Benth) against erythrocytic stage of mice infective chloroquine sensitive Plasmodium berghei NK-65. Brit. J. Applied Sc. Tech. 2011;1(3):131-140.

32. Alli LA, Adesokan AA, Salawu OA, Akanji MA, Tijani AY. Anti-plasmodial activity of aqueous root extract of Acacia nilotica. Afric. J. Biochem. Res. 2011;5(7):214-219.

33. Kirira PG, Rukunga GM, Wanyonyi AW, Muregi FM, Gathirwa JW, Muthaura CN, Omar SA, Tolo F, Mungai GM, Ndiege IO. Anti-plasmodial activity and toxicity of extracts of plants used in traditional malaria therapy in Meru and Kilifi Districts of Kenya. J. Ethnopharmacol. 2006;106(3);403-407.

34. Anyanwu GI, Uloko JL. Evaluation of insecticidal effects of Lantana camara (Verbenaceae) on mosquito adults and larvae. West Afric. J. Pharmacol. Drug Res. 1997;13(1,2):23-26.

(c) 2014 Dawet et al.; This is an Open Access article distributed under the terms of the Creative Commons Attribution License (http://creativecommons.org/licenses/by/3.0), which permits unrestricted use, distribution, and reproduction in any medium, provided the original work is properly cited.

Peer-review history:

The peer review history for this paper can be accessed here: http://www.sciencedomain.org/review-history.php?iid=375\&id=13\&aid=3284 